\title{
Strategies of adoptive $T$-cell transfer to treat refractory viral infections post allogeneic stem cell transplantation
}

\author{
Theresa Kaeuferle ${ }^{1}$, Ramona Krauss ${ }^{1}$, Franziska Blaeschke ${ }^{1}$, Semjon Willier ${ }^{1}$ and Tobias Feuchtinger $^{1,2^{*}}$ (D)
}

\begin{abstract}
Background: Allogeneic hematopoietic stem cell transplantation (HSCT) can expose patients to a transient but marked immunosuppression, during which viral infections are an important cause of morbidity and mortality. Adoptive transfer of virus-specific T cells is an attractive approach to restore protective $T$-cell immunity in patients with refractory viral infections after allogeneic HSCT.
\end{abstract}

Objectives: This narrative review summarizes clinical evidence and developments of almost 30 years of adoptive $\mathrm{T}$-cell transfer. The review is based on evidence extracted from PubMed searches and the clinical and experimental work of the authors.

Content: Viral infections after HSCT are frequently caused by the endogenous reactivation of persistent pathogens such as cytomegalovirus (CMV), Epstein-Barr virus (EBV), and adenovirus (AdV). Current antiviral medication is not satisfactory and does not treat the underlying pathophysiology which is the lack of specific $T$-cell immunity. Adoptive transfer of virus-specific T cells could be a potentially curative, pathogen-specific, and non-toxic treatment providing long-term immunity against the virus. The isolation of virus-specific T cells from a healthy donor and infusion into a recipient is known as adoptive $T$-cell transfer and has been performed in many patients using different treatment protocols. Based on basic research, new isolation protocols aim at a safe and fast availability of cellular products for adoptive $T$-cell transfer. We summarize preclinical and clinical data on each of the main pathogens and on the technical approaches currently available to target either single antigens or even multiple pathogens.

Conclusion: Cellular therapy is considered as one of the major recent breakthroughs in medicine. Translation of this individualized treatment into first-line clinical routine is still limited. Main hurdles are availability of the technique, limited compatibility of classical phase III designs with cellular therapy, and regulatory restrictions. Multinational efforts are required to clarify the status of cellular treatment in first-line clinical routine with the overall objective to strengthen evidence-based treatment guidelines for the treatment of refractory viral infections post HSCT.

Keywords: Adoptive T cell transfer, Virus-specific T cells, Refractory viral infections

\section{Introduction}

Allogeneic hematopoietic stem cell transplantation (HSCT) cures a variety of diseases, but it exposes patients to a transient severe immune deficiency. Since immune reconstitution after allogeneic HSCT can take 3 to 6 months [1-3], infections are a major cause of morbidity and mortality during this phase of immune deficiency. Taken together,

\footnotetext{
* Correspondence: tobias.feuchtinger@med.uni-muenchen.de

'Department of Pediatric Hematology, Oncology, Hemostaseology and Stem Cell Transplantation, Dr. von Hauner University Children's Hospital, Ludwig Maximilian University Munich, Lindwurmstrasse 4, 80337 Munich, Germany ${ }^{2}$ German Center for Infection Research (DZIF), Munich, Germany
}

infections cause $11 \%$ of all deaths after HSCT occurring with a median of 3 months after transplantation. About one third of infection-related deaths are caused by viruses, mainly human cytomegalovirus (CMV), Epstein-Barr virus (EBV), or human adenovirus (AdV) [4].

CMV is rarely associated with significant symptoms in healthy adults but causes severe complications during gestation and in immunocompromised patients [5]. EBV causes infectious mononucleosis but usually only mild, self-limiting disease followed by a lifelong latency of the virus in B cells. After HSCT, the latent virus can be

(C) The Author(s). 2019 Open Access This article is distributed under the terms of the Creative Commons Attribution 4.0 International License (http://creativecommons.org/licenses/by/4.0/), which permits unrestricted use, distribution, and 
reactivated and manifests as post-transplant lymphoproliferative disease (PTLD) [6, 7]. AdV is a widely spread virus, and the vast majority of pre-school children have had at least several respiratory or gastro-intestinal infections with AdV. AdV infections after HSCT show a particularly high incidence in pediatric patients. Local reactivations are often self-limiting, whereas systemic infections in the presence of a risk factor causing reduced $\mathrm{T}$ cell protection are associated with high morbidity and mortality [8].

Conventional pharmacologic agents against AdV and EBV have limited efficacy and relevant toxicity $[9,10]$. Pharmacological treatment of CMV shows better response rates, but toxicity and reactivation after treatment stop are frequent [11]. A sustained control of refractory viral infections will depend ultimately on the restoration of adequate antiviral immunity. Adoptive transfer of virus-specific T cells is an attractive approach to improve immune protection [7] (Fig. 1). This protection has been best described by the detection of specific $\mathrm{T}$-cell responses in peripheral blood. For other predictive biomarkers, only few data exist. First, immunosuppression is likely to suppress antiviral $\mathrm{T}$-cell responses. Under high doses of steroids, a success of adoptive $\mathrm{T}$ -cell therapy has not been possible. In theory, calcineurin inhibitors suppress $\mathrm{T}$-cell responses, but systematic data are missing. Second, classical transplant parameters (donor type, human leukocyte antigen (HLA) match, underlying disease) have not been associated with differences in outcome of specific $\mathrm{T}$-cell transfer. $\mathrm{T}$ cells from the initial HSCT-donor have been more successful compared to third-party donors [12]. Last but not the least, routine use of adoptive $T$-cell therapy requires $T$ cells from seropositive donors. Therefore, we recommend testing of the donor for specific $\mathrm{T}$-cell responses before adoptive $\mathrm{T}$ cell transfer.

Current development of chimeric antigen receptor (CAR) $\mathrm{T}$ cells for the treatment of leukemia and lymphoma has raised the question of a CAR T cell therapy against persistent viral infections post HSCT [13]. However, neither a combination of virus-specific $\mathrm{T}$-cell receptor (TCR) with an anti-tumor CAR [14] nor an anti-viral CAR alone has been proven superior to an endogenous TCR.

In the context of recent reviews on this topic [15-17], this review illustrates the development of selection techniques for isolation of virus-specific $\mathrm{T}$ cells and summarizes almost 30 years of clinical evidence from studies using CMV-, EBV-, and AdV-specific $\mathrm{T}$ cells for adoptive $\mathrm{T}$ cell transfer.

\section{Development of selection techniques of virus- specific T cells \\ Donor lymphocyte infusion}

During the 1990s, viral infections after allogeneic HSCT frequently took a fatal course. The initial protocols of adoptive $\mathrm{T}$-cell transfer were based on donor lymphocyte infusions (DLIs) which mediated antiviral activity with promising results $[18,19]$. Unfortunately, unmanipulated DLIs provide relative high frequencies of alloreactive $T$ cells resulting in a significant risk for graft-versus-host disease (GvHD) [20]. Therefore, different strategies have been developed to enrich, isolate, or purify virus-specific $\mathrm{T}$ cells.

In vitro stimulation and expansion of virus-specific T cells Riddell and Greenberg set up a protocol in which solely virus-specific $\mathrm{T}$ cells are infused into the patient $[21,22]$. They generated CMV-specific $\mathrm{CD}^{+} \mathrm{T}$ cells by ex vivo culture of donor peripheral blood mononuclear cells (PBMCs) in the presence of CMV-infected autologous fibroblasts followed by clonal expansion and depletion of $\mathrm{CD}^{+} \mathrm{T}$ cells. None of the treated patients showed significant side effects [21, 22]. However, these first results indicated the need of $\mathrm{CD} 4^{+} \mathrm{T}$ cells for prolonged survival of the adoptively transferred $\mathrm{CD}^{+} \mathrm{T}$ cell clones in vivo, so that Einsele and colleagues established a

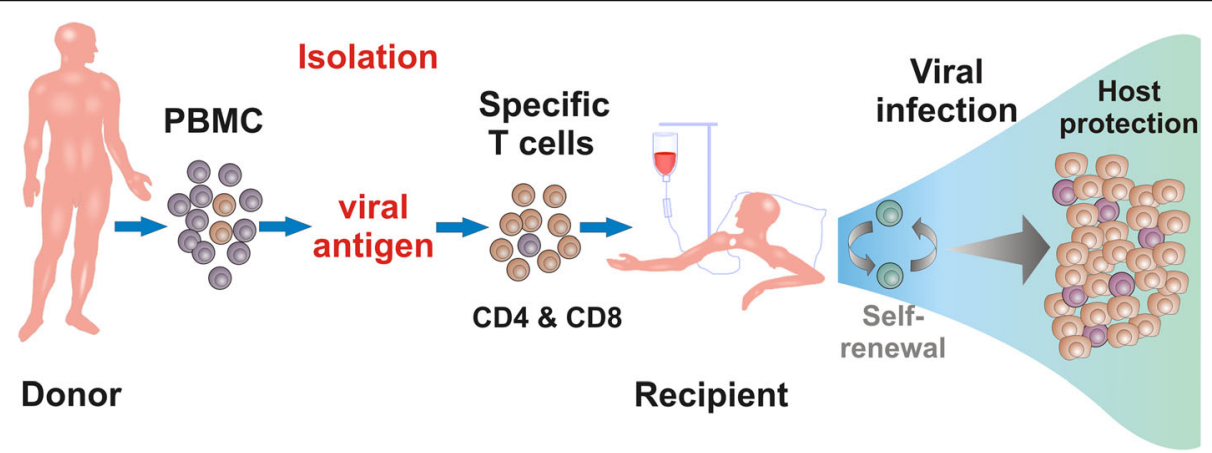

Fig. 1 Adoptive T cell transfer. Adoptive transfer of multivirus-specific T cells from a healthy donor to a patient in order to treat refractory viral infections post stem cell transplantation (HSCT). Virus-specific T cells can be isolated by in vitro stimulation and expansion or direct selection of specific T cells ex vivo from peripheral blood of a seropositive donor 
protocol for the isolation of $\mathrm{CMV}$-specific polyclonal $\mathrm{CD}^{+}{ }^{+}$and $\mathrm{CD}^{+} \mathrm{T}$ cells [23]. To remove potentially infective virus from the protocol, Peggs et al. pulsed autologous dendritic cells (DCs) with viral lysate instead of using CMV-infected autologous cells. Pulsed DCs were used as antigen-presenting cells (APCs) to restimulate CMV-specific T cells [24]. Rooney and colleagues generated EBV-specific $\mathrm{T}$ cells by successively stimulating donor-derived PBMCs with irradiated autologous EBVtransformed B cell lines (LCLs) to treat PTLD [25, 26] (Fig. 2).

Although virus-specific $\mathrm{T}$-cell products can be generated in clinically useful numbers from a small volume of blood by in vitro stimulation and expansion, further efforts have been made to directly isolate virus-specific $\mathrm{T}$ cells from peripheral blood of a seropositive donor without in vitro expansion. Directly selected virus-specific $\mathrm{T}$ cells are supposed to proliferate more efficiently under physiological conditions in vivo than extensively in vitro cultured $\mathrm{T}$ cells. Moreover, it was shown that clonal expansion of virus-specific $\mathrm{T}$ cells in vitro is associated with an upregulated expression of the pro-apoptotic molecule Fas and a lack of CD28 expression, possibly due to overstimulation of the $\mathrm{T}$ cells [27].

\section{Direct selection of virus-specific $T$ cells}

For direct selection of virus-specific T cells, donor white blood cells are isolated ex vivo via peptide-HLA multimers, cytokine-capture method [28-30] after exposure to viral antigen, or methods based on expression and upregulation of activation molecules [31] on the surface of $\mathrm{T}$ cells. Virus-specific $\mathrm{T}$ cells are obtained in small amounts and are infused into the patient where they can expand effectively and induce viral clearance as well as sustained protection. However, this method implies a second blood donation of the HSCT donor, who additionally needs to show a sufficient population of virus-specific $\mathrm{T}$ cells to enable successful manufacturing of a $\mathrm{T}$-cell product.

Human leukocyte antigen (HLA) multimers loaded with a virus-specific peptide allow highly specific labeling of virus-specific T cells [32, 33] (Fig. 2). Keenan et al. combined this labeling method with magnetic separation for purification of CMV-specific $\mathrm{CD} 8^{+} \mathrm{T}$ cells from PBMCs [34]. Recently, HLA multimers called streptamers were monomerized after isolation of peptide-specific $\mathrm{T}$ cells by adding a competitor followed by dissociation from the $\mathrm{T}$ cell before infusion into the patient [35]. However, since availability of multimers is restricted to HLA class I and specific epitopes, this technology enables generation of

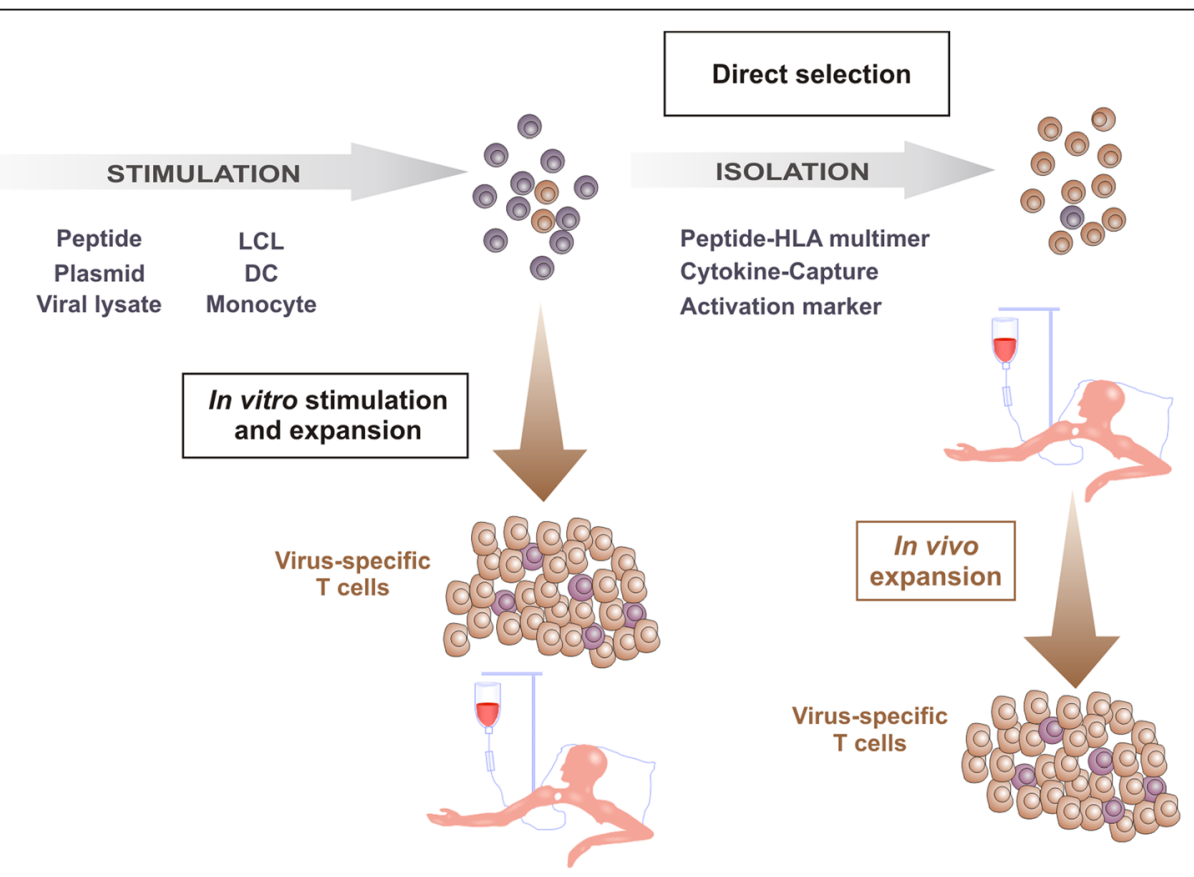

Fig. 2 Selection techniques for the isolation of virus-specific T cells. Generation of virus-specific T cells by in vitro stimulation and expansion or direct selection. Firstly, cells are stimulated specifically via viral peptide/protein/lysate or antigen-presenting cells. Secondly, cells can either be used for in vitro expansion or isolation and direct infusion into the patient. Large amounts of virus-specific T cells can be obtained from a small starting volume of blood by in vitro stimulation and expansion. T -cell products from direct selection of virus-specific cells via peptide HLA multimers, cytokine-capture technique, or activation markers are obtained in small amounts and are infused into the patient where they expand under physiological conditions 
$\mathrm{CD}^{+} \mathrm{T}$ cells only against known immunodominant $\mathrm{T}$-cell epitopes.

The cytokine-capture approach is a rapid method to isolate functional $\mathrm{CD}_{4}^{+}$and $\mathrm{CD}^{+} \mathrm{T}$ cells based on activation-induced release of interferon- $\gamma$ (IFN $\gamma$ ) after stimulation with viral antigen (Fig. 2). Donor PBMCs are stimulated with viral antigen or viral lysate and labeled with a leukocyte-specific (CD45) antibody conjugated to an anti-IFN $\gamma$ antibody. After the cytokine-capture period, specifically activated $\mathrm{T}$ cells are magnetically labeled via captured IFN $\gamma$ on the surface allowing subsequent enrichment via a magnetic column [36, 37].

Another approach to isolate virus-specific $\mathrm{T}$ cells according to their activation after antigen stimulation is based on the activation-induced expression of specific surface molecules, such as CD137 (4-1BB) [38] and CD154 (CD40L) [39] and subsequent enrichment via a magnetic column.

\section{Generation of multivirus-specific T cells}

Since the generation of adoptive $\mathrm{T}$-cell therapy for each single virus in a separate manufacturing process is timeand cost-consuming, there are strong efforts to establish protocols for the generation of multivirus-specific $\mathrm{T}$ cells in one single step. One method is based on the generation of EBV-specific $T$ cells by repetitively stimulating and expanding PBMCs with LCLs [25, 26]. Leen et al. used irradiated autologous LCLs transduced with an adenoviral vector expressing the CMV antigen pp65. These LCLs served as antigen-presenting cells for the inherent EBV antigens, the adenoviral hexon antigen from the capsid of the vector, and pp65 from the vector transfection to stimulate PBMCs specific for CMV, EBV, and AdV [40]. These manufacturing processes require several weeks.

Therefore, several efforts were made to reduce the manufacturing time like stimulation of donor-derived PBMCs with autologous monocytes transduced with either Ad5f35-CMV-pp65 (AdV and CMV) vector or Ad5f35-EBV-LMP2 (AdV and EBV) vector. After stimulation of CMV-, EBV-, and AdV-specific T cells, an isolation step could be added using the cytokine-capture technique [41]. Another approach was the use of DCs nucleofected with plasmids encoding pp65 (CMV), IE1 (CMV), LMP2 (EBV), EBNA1 (EBV), BZLF1 (EBV), Hexon (AdV), and Penton (AdV). After nucleofection, the DCs were used as APCs for stimulation of CMV-, EBV-, and AdV-specific $\mathrm{T}$ cells. Generation of multivirus-specific $\mathrm{T}$ cells with this protocol can be performed in 11 to 12 days [42].

Furthermore, multivirus-specific $\mathrm{T}$ cells have already been produced using direct isolation via the cytokinecapture technique [43], and Khanna et al. described a protocol where multipathogen-specific $\mathrm{T}$ cells expressing
CD154 were directly isolated via magnetic cell separation [31]. A comparison of multivirus-specific $\mathrm{T}$ cells isolated based on either CD137 expression or IFNY production showed no significant differences in functionality or $\mathrm{CD}^{+} / \mathrm{CD}^{+} \mathrm{T}$-cell frequencies [44].

\section{Clinical evidence \\ Cytomegalovirus}

The first clinical application of adoptive $\mathrm{T}$-cell therapy against viral infections was done with CMV-specific T cells in 1992 [22] (Table 1). Riddell and Greenberg treated three patients with repetitive infusions of escalating numbers of in vitro expanded $\mathrm{CMV}$-specific $\mathrm{CD}^{+} \mathrm{T}$ -cell clones over 4 weeks. None of the three patients showed severe side effects and also none of them developed CMV viremia or pneumonia [22]. Accordingly, a further study with 14 patients using in vitro expansion to generate CMV-specific T cells confirmed the absence of toxic effects and confirmed CMV-specific immune reconstitution in all treated patients [45]. Einsele and colleagues extended the protocol and treated eight infected patients with polyclonal CMV-specific $\mathrm{CD}_{4}^{+}$ and $\mathrm{CD} 8^{+} \mathrm{T}$ cells. Five out of seven evaluable patients cleared the infection completely, whereas one of these patients did not respond until a second infusion of CMV-specific T cells [23]. Another study performed by Peggs et al. showed massive expansion of infused polyclonal CMV-specific $\mathrm{CD} 4^{+}$and $\mathrm{CD}^{+} \mathrm{T}$ cells after adoptive transfer and recovery of immune response in all patients [46]. The first adoptive transfer of tetramer-selected $\mathrm{CD}^{+}{ }^{+} \mathrm{T}$ cells was done by Cobbold and his colleagues. Despite the relatively low doses in comparison to the other studies, eight of nine patients cleared the virus completely [47]. Two patients treated with $\mathrm{CMV}$-specific $\mathrm{CD}^{+} \mathrm{T}$ cells generated via the reversible streptamer technique showed long-lasting responses and control of CMV viremia [48]. In a recent phase I/IIa study, patients were treated with streptamer-isolated CMV-specific $\mathrm{T}$ cells, generated either from their stem cell donor or from partially HLA-matched third-party donors [12]. Seven of seven eligible patients treated with stem cell donor-derived $\mathrm{T}$ cells reduced or cleared viral load whereas five of eight patients responded after transfer of third-party donor-derived $\mathrm{T}$ cells [12]. Adoptive $\mathrm{T}$-cell transfer of CMV-specific $\mathrm{T}$ cells isolated by cytokine-secretion assay led to viral clearance or significant reduction of viral load in 15 of 18 treated patients [28].

\section{Epstein-Barr virus}

Rooney et al. published a first study with EBV-specific $\mathrm{T}$ cells generated by repetitive stimulation of donor-derived PBMCs with irradiated autologous EBV-transformed B cell lines for the treatment of EBV-associated PTLD [25] 
Table 1 Clinical evidence for adoptive transfer of CMV-specific T cells

\begin{tabular}{|c|c|c|c|c|}
\hline Reference & Method & $\begin{array}{l}\text { No. of } \\
\text { patients }\end{array}$ & Results & Dose \\
\hline \multicolumn{5}{|l|}{ In vitro stimulation and expansion } \\
\hline Riddell et al. (1992) [22] & $\begin{array}{l}\text { Allogeneic CMV-spec. } \\
\mathrm{CD}^{+} \text {clones }\end{array}$ & 3 & $\begin{array}{l}3 / 3 \text { prevention of viremia } \\
\text { and pneumonia }\end{array}$ & $3.3 \times 10^{7}-10^{9} \mathrm{cells} / \mathrm{m}^{2}$ \\
\hline Walter et al. (1995) [45] & $\begin{array}{l}\text { Allogeneic CMV-spec. } \\
\mathrm{CD}^{+} \text {clones phase I }\end{array}$ & $14(11)$ & $\begin{array}{l}\text { 11/11 prevention of } \mathrm{CMV} \\
\text { infection }\end{array}$ & $3.3 \times 10^{7}-10^{9} \mathrm{cells} / \mathrm{m}^{2}$ \\
\hline Einsele et al. (2002) [23] & $\begin{array}{l}\text { Allogeneic CMV-spec. } \\
\text { polyclonal CD } 8^{+} \text {and } \\
\mathrm{CD} 4^{+} \mathrm{T} \text { cells }\end{array}$ & 8 & $\begin{array}{l}5 / 7 \text { evaluable patients } \\
\text { eliminated infection }\end{array}$ & $10^{7}$ cells $/ \mathrm{m}^{2}$ \\
\hline Peggs et al. (2003) [46] & $\begin{array}{l}\text { Allogeneic CMV-specific } \\
\text { polyclonal CD8 } 8^{+} \text {and } \\
\mathrm{CD} 4^{+} \mathrm{T} \text { cells }\end{array}$ & 16 & $\begin{array}{l}14 / 16 \text { no viral reactivation, reconstitution } \\
\text { of antiviral immunity }\end{array}$ & $10^{5}$ cells $/ \mathrm{kg}$ \\
\hline Perruccio et al. (2005) [56] & $\begin{array}{l}\text { Allogeneic CMV-specific } \\
\mathrm{CD}^{+} \text {clones }\end{array}$ & $\begin{array}{l}25 \\
\text { prophylaxis }\end{array}$ & $\begin{array}{l}\text { 7/25 patients had CMV-reactivation, } \\
5 / 25 \text { patients developed CMV-disease } \\
\text { ( } 3 \text { eliminated infection) }\end{array}$ & $10^{5}-3 \times 10^{6}$ cells $/ \mathrm{kg}$ \\
\hline Meji et al. (2012) [57] & $\begin{array}{l}\text { CMV-specific polyclonal CD8 }{ }^{+} \\
\text {and } C D 4^{+} T \text { cells phase } 1 / \|\end{array}$ & 6 & $6 / 6$ patients eliminated infection & $0.9 \times 10^{4}-3.1 \times 10^{5}$ cells $/ \mathrm{kg}$ \\
\hline Pei et al. (2017) [58] & $\begin{array}{l}\text { CMV-specific cytokine induce } \\
\text { effector cells phase I }\end{array}$ & 32 & $27 / 32$ responded & $\begin{array}{l}0.66-15.41 \times 10^{7} \mathrm{CD}^{+}{ }^{+} \text {and } \\
0.68-9.25 \times 10^{5} \mathrm{CD}^{+}\end{array}$ \\
\hline Withers et al. (2017 and 2018) [55, 59] & $\begin{array}{l}\text { CMV-specific third-party CD8+ } \\
\text { and CD4+ T cells phase I }\end{array}$ & 27 & $26 / 27$ responded & $1.37-5.0 \times 10^{7}$ cells $/ \mathrm{m}^{2}$ \\
\hline \multicolumn{5}{|l|}{ Direct isolation via peptide-HLA multimers } \\
\hline Cobbold et al. (2005) [47] & $\begin{array}{l}\text { Allogeneic CMV-specific CD8 }{ }^{+} \\
\text {T cells using MHC--tetramers }\end{array}$ & 9 & 8/9 patients eliminated infection & $1.2-33 \times 10^{3}$ cells $/ \mathrm{kg}$ \\
\hline Schmitt et al. (2011) [48] & $\begin{array}{l}\text { Allogeneic CMV-specific CD8 }{ }^{+} \\
\text {T cells using MHC-I-streptamers }\end{array}$ & 2 & 2/2 control of CMV-viremia & 0.37 and $2.2 \times 10^{5}$ cells $/ \mathrm{kg}$ \\
\hline Uhlin et al. (2012) [60] & $\begin{array}{l}\text { Allogeneic CMV-specific CD8 } \\
\text { T cells using MHC-I-pentamers }\end{array}$ & 5 & $4 / 5$ responders & $0.8-24.6 \times 10^{4}$ cells $/ \mathrm{kg}$ \\
\hline Blyth et al. (2013) [61] & $\begin{array}{l}\text { Allogeneic CMV-specific polyclonal } \\
\mathrm{CD} 8^{+} \text {and } \mathrm{CD} 4^{+} T \text { cells phase } \|\end{array}$ & $\begin{array}{l}50 \\
\text { Prophylaxis }\end{array}$ & $\begin{array}{l}41 / 50 \text { did not require CMV- } \\
\text { directed pharmacotherapy }\end{array}$ & $2 \times 10^{7}$ cells $/ \mathrm{m}^{2}$ \\
\hline Neuenhahn et al. (2017) [12] & $\begin{array}{l}\text { Allogeneic CMV-specific CD8 }{ }^{+} \\
\text {T cells using MHC-I-streptamers } \\
\text { phase I/lla }\end{array}$ & 16 & $\begin{array}{l}\text { Stem cell donor-derived: } 7 / 7 \\
\text { responders third-party transfer: } \\
5 / 8 \text { responders }\end{array}$ & $\begin{array}{l}6.3 \times 10^{6} \text { cells (HSCT donor) } \\
1.4 \times 10^{7} \text { cells (third-party donor) }\end{array}$ \\
\hline \multicolumn{5}{|c|}{ Direct isolation via cytokine-capture technique } \\
\hline Feuchtingeret al. (2010) [28] & $\begin{array}{l}\text { CMV-specific polyclonal CD8 }{ }^{+} \text {and } \\
\text { CD4 } 4^{+} T \text { cells }\end{array}$ & 18 & $15 / 18$ responders & $1.2-166 \times 10^{3}$ cells $/ \mathrm{kg}$ \\
\hline Peggs et al. (2011) [62] & $\begin{array}{l}\text { CMV-specific polyclonal } \mathrm{CD}^{+} \text {and } \\
\mathrm{CD} 4^{+} \mathrm{T} \text { cells phase } 1 / \| \mathrm{l}\end{array}$ & 18 & $\begin{array}{l}\text { Prophylaxis: } 6 / 7 \text { virus-free } \\
\text { Pre-emptive: } 2 / 11 \text { required } \\
\text { no antiviral drug treatment }\end{array}$ & Median: $3.5 \times 10^{4}$ cells $/ \mathrm{kg}$ \\
\hline Kàllay et al. (2018) [43] & $\begin{array}{l}\text { CMV-specific polyclonal } \mathrm{CD} 8^{+} \text {and } \\
\mathrm{CD} 4^{+} \mathrm{T} \text { cells }\end{array}$ & 3 & $\begin{array}{l}2 / 3 \text { viral clearance } 1 / 3 \text { decrease in } \\
\text { viral load }\end{array}$ & $7.5-16.2 \times 10^{4}$ cells $/ \mathrm{kg}$ \\
\hline
\end{tabular}

(Table 2). Ten patients received adoptive $\mathrm{T}$ cell therapy who either had EBV reactivation or were treated prophylactically. In the three patients with EBV reactivation, EBV DNA decreased to normal. None of the seven patients who received EBV-specific T cells as prophylaxis developed EBV disease [25]. This approach was further established in a later study with 39 patients who received prophylactic infusion of EBV-specific T cells. None of the 39 patients developed EBV-related PTLD in comparison to $11.5 \%$ in a control group of 61 patients who did not receive EBV-specific adoptive T cell therapy [26]. With genetically marked adoptively transferred EBV-specific T cells, it could be shown that donor-derived $\mathrm{T}$ cells were present in the patient even 105 months after adoptive T cell transfer [49].
Haque and colleagues treated eight patients with progressive PTLD in a pilot study with EBV-specific polyclonal $\mathrm{CD}^{+}$and $\mathrm{CD}^{+}{ }^{+} \mathrm{T}$ cells generated from partially HLAmatched unrelated donors [50]. Four of the eight patients had a complete or partial remission, and none of the patients developed GvHD [50]. In a following multicenter phase II clinical trial, the response rate after 6 months was $52 \%$ [51]. Notably, in this study, infusion of higher amounts of $\mathrm{CD}_{4}^{+} \mathrm{T}$ cells led to a significantly better outcome. These data suggest that infusion of EBV-specific $\mathrm{T}$ cells induce relatively lower response rates compared to that of CMV-specific T cells. A possible explanation is that CMV is mainly controlled by a single antigen pp65 with an extraordinary high immunogenicity, whereas EBV antigens 
Table 2 Clinical evidence for adoptive transfer of EBV-specific T cells

\begin{tabular}{|c|c|c|c|c|}
\hline Reference & Method & No. of patients & Results & Dose \\
\hline \multicolumn{5}{|l|}{ In vitro stimulation and expansion } \\
\hline Rooney et al. (1995) [25] & $\begin{array}{l}\text { Allogeneic EBV-specific } \\
\mathrm{CD}^{+} \mathrm{T} \text { cells }\end{array}$ & 10 & $\begin{array}{l}\text { Therapy: } 3 / 3 \text { responders } \\
\text { Prophylaxis: } 7 / 7 \text { virus free }\end{array}$ & $0.2-1.2 \times 10^{8}$ cells $/ \mathrm{m}^{2}$ \\
\hline Rooney et al. (1998) [26] & $\begin{array}{l}\text { Allogeneic EBV-specific } \\
\mathrm{CD}^{+} \mathrm{T} \text { cells }\end{array}$ & 39 & Prophylaxis: all PTLD free & $0.2-1.0 \times 10^{8}$ cells $/ \mathrm{m}^{2}$ \\
\hline Haque et al. (2002) [50] & $\begin{array}{l}\text { Allogeneic EBV-specific } \\
\text { polyclonal CD8 }{ }^{+} \text {and } \\
C D 4^{+} T \text { cells phase } 1 / I I\end{array}$ & 8 & $4 / 8$ remission & $10^{6}$ cells $/ \mathrm{kg}$ \\
\hline Haque et al. (2007) [51] & $\begin{array}{l}\text { Allogeneic EBV-specific } \\
\text { polyclonal CD8 }{ }^{+} \text {and } \\
C D 4^{+} \text {T cells phase II }\end{array}$ & 33 & $\begin{array}{l}\text { 14/33 complete remission } \\
3 / 33 \text { partial response }\end{array}$ & $2 \times 10^{6}$ cells $/ \mathrm{kg}$ \\
\hline Heslop et al. (2010) [49] & $\begin{array}{l}\text { Allogeneic EBV-specific } \\
\mathrm{CD}^{+} \mathrm{T} \text { cells }\end{array}$ & 114 & $\begin{array}{l}\text { Therapy: 11/13 complete } \\
\text { response prophylaxis: } \\
\text { all PTLD free }\end{array}$ & $1-5 \times 10^{7}$ cells $/ \mathrm{m}^{2}$ \\
\hline Doubrovina et al. (2012) [63] & $\begin{array}{l}\text { Allogeneic EBV-specific } \\
\mathrm{CD}^{+} \mathrm{T} \text { cells }\end{array}$ & 19 & 13/19 complete response & $10^{6}$ cells $/ \mathrm{kg}$ \\
\hline Gallot et al. (2014) [64] & $\begin{array}{l}\text { Allogeneic EBV-specific } \\
\text { polyclonal } C D 8^{+} \text {and } \\
\mathrm{CD}^{+} \mathrm{T} \text { cells phase } \mathrm{I} / \mathrm{II}\end{array}$ & 11 & $4 / 10$ responders & $5 \times 10^{6}$ cells $/ \mathrm{kg}$ \\
\hline Withers et al. (2017 and 2018) $[55,59]$ & $\begin{array}{l}\text { EBV-specific third-party CD8+ } \\
\text { and CD4+ T cells phase I }\end{array}$ & 1 & 0/1 responded & $\begin{array}{l}1 \text { infusion of } 1.37-5.0 \times 10^{7} \\
\text { cells } / \mathrm{m}^{2}\end{array}$ \\
\hline \multicolumn{5}{|l|}{ Direct isolation via peptide-HLA multimers } \\
\hline Uhlin et al. (2010) [65] & $\begin{array}{l}\text { Allogeneic EBV-specific CD8 }{ }^{+} \\
\text {T cells using MHC-I-pentamers }\end{array}$ & 1 & 1/1 complete response & $\begin{array}{l}1.1 \times 10^{4} \mathrm{cell} / \mathrm{s} / \mathrm{kg} \text { and } \\
2 \times 10^{4} \mathrm{cell} / \mathrm{kg}\end{array}$ \\
\hline \multicolumn{5}{|c|}{ Direct isolation via cytokine-capture technique } \\
\hline Moosmann et al. (2010) [66] & $\begin{array}{l}\text { EBV-specific polyclonal } \mathrm{CD}^{+} \\
\text {and } \mathrm{CD}^{+} \mathrm{T} \text { cells }\end{array}$ & 6 & $3 / 6$ responders & $0.4-9.7 \times 10^{4}$ cells $/ \mathrm{kg}$ \\
\hline Icheva et al. (2013) [29] & $\begin{array}{l}\text { EBV-specific polyclonal CD8 }{ }^{+} \\
\text {and } \mathrm{CD}^{+} \mathrm{T} \text { cells }\end{array}$ & 10 & $7 / 10$ responders & $0.15-53.8 \times 10^{3} \mathrm{cell} / \mathrm{s} / \mathrm{kg}$ \\
\hline Kàllay et al. (2018) [43] & $\begin{array}{l}\text { EBV-specific polyclonal CD8 }{ }^{+} \\
\text {and CD4 }{ }^{+} T \text { cells }\end{array}$ & 2 & $2 / 2$ responders & $1.8-2.3 \times 10^{4} \mathrm{cell} / \mathrm{s} / \mathrm{kg}$ \\
\hline
\end{tabular}

induce less strong $\mathrm{T}$ cell responses. Nevertheless, by using the same technique for different viruses, a comparable result could be achieved: Icheva et al. were able to treat 10 patients with PTLD- and EBV-related complications with small doses of EBNA1-specific T cells isolated by cytokinecapture technique and describe a clinical and virological response in 7 out of 10 patients [29].

\section{Adenovirus}

In a first study using adoptive transfer of AdV-specific $\mathrm{T}$ cells, nine children with systemic AdV infection after allogeneic HSCT were treated with cells isolated by cytokine-capture technique based on IFN $\gamma$ secretion [52] (Table 3). Despite the relatively low number of infused $\mathrm{T}$ cells, five of six evaluable patients cleared the infection or showed a decrease in viral load which was associated with expansion of AdV-specific $\mathrm{T}$ cells in vivo. These results indicate that even low numbers of adoptively transferred virus-specific $\mathrm{T}$ cells are able to expand in vivo in the presence of viral antigen. Further, no acute toxicities or GvHD induction have been documented [52]. Virus-specific T cells generated by in vitro stimulation and expansion were administered to two patients with rising AdV load and led to complete clearance or more than 1.5 $\log$ reduction of viral load in all of the three patients [53]. Refractory AdV infection was treated with hexon-specific $\mathrm{T}$ cells generated via cytokine-capture technique in a study with 30 patients. Twenty-one of these patients responded to adoptive $\mathrm{T}$ cell transfer without relevant side effects [30].

\section{Multivirus-specific (CMV, EBV, and AdV) T cell therapy}

The first clinical application of multivirus-specific $\mathrm{T}$ cells was published in 2006 by Leen and her colleagues [40] (Table 4). Adoptive transfer was performed in 11 patients where trivirus-specific T cells, generated by in vitro stimulation and expansion, expanded and provided long-term immunity. Notably, all patients with a CMV, EBV, or AdV infection cleared the infection. In contrast to CMV- and EBV-specific T cells, the expansion of AdV-specific T cells 
Table 3 Clinical evidence for adoptive transfer of AdV-specific T cells

\begin{tabular}{|c|c|c|c|c|}
\hline Reference & Method & $\begin{array}{l}\text { No. of } \\
\text { patients }\end{array}$ & Results & Dose \\
\hline \multicolumn{5}{|l|}{ In vitro stimulation and expansion } \\
\hline Geyeregger et al. (2014) [53] & $\begin{array}{l}\text { Allogeneic AdV-specific } \\
\text { polyclonal CD8 } 8^{+} \text {and } \\
\text { CD4 }^{+} T \text { cells }\end{array}$ & 2 & $\begin{array}{l}1 / 2 \text { complete response } \\
1 / 2 \text { partial response }\end{array}$ & $10^{4} \mathrm{CD}^{+}$cells $/ \mathrm{kg}$ \\
\hline Withers et al. (2017 and 2018) [55, 59] & $\begin{array}{l}\text { AdV-specific third-party } \\
\text { CD8+ and CD4+ } \\
\text { T cells phase I }\end{array}$ & 1 & $1 / 1$ responded & $\begin{array}{l}1 \text { infusion of } 1.37-5 \times 10^{7} \\
\text { cells } / \mathrm{m}^{2}\end{array}$ \\
\hline \multicolumn{5}{|l|}{ Direct isolation via peptide-HLA multimers } \\
\hline Uhlin et al. (2012) [60] & $\begin{array}{l}\text { Allogeneic AdV-specific } \\
C D 8^{+} T \text { cells using } \\
\text { MHC-I-pentamers }\end{array}$ & 8 & $5 / 6$ responders & $\begin{array}{l}3.1 \times 10^{4} \text { and } 1.7 \times 10^{4} \\
\text { cells } / \mathrm{kg}\end{array}$ \\
\hline \multicolumn{5}{|c|}{ Direct isolation via cytokine-capture technique } \\
\hline Feuchtinger et al. (2006) [52] & $\begin{array}{l}\text { AdV-specific polyclonal } \\
\mathrm{CD}^{+} \text {and } \mathrm{CD} 4^{+} \mathrm{T} \text { cells }\end{array}$ & 9 & $5 / 6$ responders & $1.2-50 \times 10^{3} \mathrm{cells} / \mathrm{kg}$ \\
\hline Qasim et al. (2013) [67] & $\begin{array}{l}\text { AdV-specific polyclonal } \\
\mathrm{CD}^{+} \text {and } C D 4^{+} T \text { cells }\end{array}$ & 5 & $3 / 5$ responders & $10^{4}$ cells $/ \mathrm{kg}$ \\
\hline Feucht et al. (2015) [30] & $\begin{array}{l}\text { AdV-specific polyclonal } \\
\text { CD8 } 8^{+} \text {and } C D 4^{+} T \text { cells }\end{array}$ & 30 & $21 / 30$ responders & $0.3-24 \times 10^{3} \mathrm{CD}^{+}$cells $/ \mathrm{kg}$ \\
\hline Kàllay et al. (2018) [43] & $\begin{array}{l}\text { AdV-specific polyclonal } \\
\mathrm{CD}^{+} \text {and } \mathrm{CD} 4^{+} \mathrm{T} \text { cells }\end{array}$ & 1 & 1/1 responder & $2.7 \times 10^{4}$ cells $/ \mathrm{kg}$ \\
\hline
\end{tabular}

seemed to depend on the presence of adenoviral antigen: CMV- and EBV-specific cytotoxic T lymphocytes (CTLs) consistently expanded in vivo after administration, whereas adenovirus-specific CTLs expanded only in individuals with active or recent adenoviral infection. In 2009, Leen et al. generated bivirus-specific $\mathrm{T}$ cell lines by in vitro stimulation and expansion [54]. AdVand EBV-specific T cells were administered to pediatric transplantation recipients with partially HLA-matched and haploidentical stem cell grafts. None of the patients developed GvHD and none of these 13 high-risk recipients developed EBV-associated lymphoproliferative disease, while two of the subjects showed resolution of their adenoviral disease [54]. In a recent study, Kállay et al. treated three patients with multivirus-specific $\mathrm{T}$ cells generated by direct isolation via the cytokine-

Table 4 Clinical evidence for adoptive transfer of multivirus-specific T cells

\begin{tabular}{|c|c|c|c|c|}
\hline Reference & Method & No. of patients & Results & Dose \\
\hline \multicolumn{5}{|c|}{ In vitro stimulation and expansion } \\
\hline Leen et al. (2006) [40] & $\begin{array}{l}\text { Allogeneic CMV-, EBV, and } \\
\text { AdV-specific CD8 }{ }^{+} T \text { cells }\end{array}$ & 11 & $\begin{array}{l}\text { All patients eliminated } \\
\text { the viral pathogen }\end{array}$ & $\begin{array}{l}5 \times 10^{6}-1 \times 10^{8} \\
\text { cells } / \mathrm{m}^{2}\end{array}$ \\
\hline Leen et al. (2009) [54] & $\begin{array}{l}\text { Allogeneic EBV- and } \\
\text { AdV-specific CD8 }{ }^{+} T \text { cells }\end{array}$ & 13 & $\begin{array}{l}\text { Therapy: 2/2 AdV clearance } \\
\text { prophylaxis: } 13 / 13 \text { no PTLD }\end{array}$ & $\begin{array}{l}0.5-13.5 \times 10^{7} \\
\text { cells } / \mathrm{m}^{2}\end{array}$ \\
\hline Gerdemann et al. (2013) [68] & $\begin{array}{l}\text { Allogeneic CMV-, } \\
\text { EBV, and AdV- specific } \\
\text { CD8 }^{+} T \text { cells phase I/II }\end{array}$ & $\begin{array}{l}10 \text { (infections: } \\
3 \mathrm{CMV}, 1 \mathrm{AdV}, \\
2 \mathrm{EBV}, 2 \mathrm{EBV}+\mathrm{AdV}, \\
2 \mathrm{CMV}+\mathrm{AdV})\end{array}$ & $\begin{array}{l}8 / 10 \text { complete } \\
\text { responses }\end{array}$ & $\begin{array}{l}5 \times 10^{6}-2 \times 10^{7} \\
\text { cells } / \mathrm{m}^{2}\end{array}$ \\
\hline $\begin{array}{l}\text { Withers et al. } \\
(2017 \text { and 2018) }[55,59]\end{array}$ & $\begin{array}{l}\text { Third-party CD8+ } \\
\text { and CD4+ CMV-, } \\
\text { EBV, AdV, and } \\
\text { varicella-zoster } \\
\text { virus-specific } \\
\text { T cells phase I }\end{array}$ & 1 & $1 / 1$ responded & $\begin{array}{l}3 \text { infusions of } \\
1.37-5 \times 10^{7} \\
\text { cells } / \mathrm{m}^{2}\end{array}$ \\
\hline \multicolumn{5}{|c|}{ Direct isolation via cytokine-capture technique } \\
\hline Kàllay et al. (2018) [43] & $\begin{array}{l}\text { CMV- and EBV-specific } \\
\text { or CMV- and AdV-specific } \\
\mathrm{CD}^{+} \text {and } C D 4^{+} \mathrm{T} \text { cells }\end{array}$ & $\begin{array}{l}3 \text { (infections: } \\
2 C M V+A d V \\
1 C M V+E B V)\end{array}$ & $3 / 3$ responders & $\begin{array}{l}3.2-4.8 \times 10^{4} \\
\text { cells } / \mathrm{kg}\end{array}$ \\
\hline
\end{tabular}


capture technique [43]. All patients became asymptomatic and decreased/cleared viral load, but one patient died later due to invasive aspergillosis.

\section{Conclusion and future perspective}

Viral infections refractory to antiviral chemotherapy are a life-threatening condition in immunocompromised hosts. Clinical trials using CMV-, EBV-, and AdV-specific T cells for adoptive $\mathrm{T}$-cell transfer have shown that $\mathrm{T}$-cell therapy is an attractive approach to restore protective antiviral $\mathrm{T}$ -cell immunity. In almost 30 years of adoptive $\mathrm{T}$-cell transfer, $74 \%$ of 246 evaluable, published patients responded to the treatment. In total, $85 \%$ responded to CMV-specific T cell transfer, $62 \%$ to EBV-specific $\mathrm{T}$ cells, and $74 \%$ to AdV-specific $T$ cell transfer.

Dosing of virus-specific $\mathrm{T}$ cells depends on the risk of GvHD, method of generation, and the grade of HLA match/mismatch. For ex vivo-generated T cells, we currently recommend an upper dose limit of $2.5 \times 10^{4} / \mathrm{kg}$ recipient body weight $\mathrm{CD}^{+}$cells in HLA-mismatched/ haploidentical donors and $1 \times 10^{5} / \mathrm{kg}$ in HLA-matched donors. A recommendation of a lower threshold does not exist at the moment. Lowest successful doses have been published as low as a few hundred cells. Protocols with longer in vitro culture steps have used higher doses.

Developing techniques for manufacturing virus-specific $\mathrm{T}$-cell products has overcome initial difficulties of adoptive $\mathrm{T}$-cell transfer. Nevertheless, the regulatory hurdles, logistics, and time-consuming selection techniques for producing virus-specific $\mathrm{T}$-cell grafts have limited widespread application of this therapy. Off-the-shelf production of a $\mathrm{T}$ -cell product is promising, but clinical efficacy has not yet been fully confirmed in placebo-controlled studies. Thirdparty $\mathrm{T}$-cells showed clinical benefits [55], but clarification of persistence in vivo remains to be investigated. A current multinational, placebo-controlled, phase III clinical trial (TRACE) aims to generate clinical evidence data to allow the inclusion of adoptive transfer of virus-specific $\mathrm{T}$ cells into evidence-based treatment guidelines and make it available as standard treatment for refractory viral infections post $\mathrm{HSCT}$ in the future.

\footnotetext{
Abbreviations

AdV: Adenovirus; APCs: Antigen-presenting cells; CMV: Cytomegalovirus; DCs: Dendritic cells; DLI: Donor lymphocyte infusion; EBV: Epstein-Barr virus; GvHD: Graft-versus-host disease; HLA: Human leukocyte antigen; HSCT: Hematopoietic stem cell transplantation; IFNy: Interferon- $\gamma$; LCLs: Autologous EBV-transformed B cell lines; PBMC: Peripheral-blood mononuclear cells; PTLD : Post-transplant lymphoproliferative disease; TRACE: Multivirus-specific T cell transfer post SCT vs AdV, CMV, and EBV infections
}

\section{Funding}

This work was supported by the European Commission Horizon2020 and the German Centre for Infection Research (DZIF).

\section{Availability of data and materials}

Not applicable. All data included in this review are obtained from the publications listed in the references.

\section{Authors' contributions}

TK and TF designed and drafted the manuscript. RK, FB, and SW revised the manuscript critically for intellectual content. TF revised the manuscript and gave final approval of the version to be published. All authors read and approved the final manuscript.

Ethics approval and consent to participate

Not applicable.

\section{Consent for publication}

Not applicable. Authors of original publications cited in this review are responsible for patients' consent.

\section{Competing interests}

The authors declare that they have no competing interests.

\section{Publisher's Note}

Springer Nature remains neutral with regard to jurisdictional claims in published maps and institutional affiliations.

Received: 5 December 2018 Accepted: 22 January 2019

Published online: 06 February 2019

\section{References}

1. Bahceci E, Epperson D, Douek DC, Melenhorst JJ, Childs RC, Barrett AJ. Early reconstitution of the T-cell repertoire after non-myeloablative peripheral blood stem cell transplantation is from post-thymic T-cell expansion and is unaffected by graft-versus-host disease or mixed chimaerism. Br J Haematol. 2003;122(6):934-43.

2. Small TN, Papadopoulos EB, Boulad F, Black P, Castro-Malaspina H, Childs $\mathrm{BH}$, et al. Comparison of immune reconstitution after unrelated and related T-cell-depleted bone marrow transplantation: effect of patient age and donor leukocyte infusions. Blood. 1999;93(2):467-80.

3. Federmann B, Hagele M, Pfeiffer M, Wirths $S$, Schumm M, Faul C, et al. Immune reconstitution after haploidentical hematopoietic cell transplantation: impact of reduced intensity conditioning and CD3/CD19 depleted grafts. Leukemia. 2011;25(1):121-9.

4. Gratwohl A, Brand R, Frassoni F, Rocha V, Niederwieser D, Reusser P, et al. Cause of death after allogeneic haematopoietic stem cell transplantation (HSCT) in early leukaemias: an EBMT analysis of lethal infectious complications and changes over calendar time. Bone Marrow Transplant. 2005;36(9):757-69.

5. Hebart $\mathrm{H}$, Einsele $\mathrm{H}$. Specific infectious complications after stem cell transplantation. SupportCare Cancer. 2004;12(2):80-5.

6. Martin-Moreno PL, Panizo C. Update on posttransplant lymphoproliferative disease. Curr Opin Nephrol Hypertens. 2018.

7. Bollard CM, Kuehnle I, Leen A, Rooney CM, Heslop HE. Adoptive immunotherapy for posttransplantation viral infections. Biol Blood Marrow Transplant. 2004;10(3):143-55.

8. Howard DS, Phillips GL II, Reece DE, Munn RK, Henslee-Downey J, Pittard M, et al. Adenovirus infections in hematopoietic stem cell transplant recipients. Clin Infect Dis. 1999;29(6):1494-501.

9. Leen AM, Bollard CM, Myers GD, Rooney CM. Adenoviral infections in hematopoietic stem cell transplantation. Biol Blood Marrow Transplant. 2006;12(3):243-51.

10. Heslop HE. How I treat EBV lymphoproliferation. Blood. 2009;114(19):4002-8.

11. Servais S, Dumontier N, Biard L, Schnepf N, Resche-Rigon M, Peffault de Latour R, et al. Response to antiviral therapy in haematopoietic stem cell transplant recipients with cytomegalovirus (CMV) reactivation according to the donor CMV serological status. Clin Microbiol Infect. 2016;22(3):289 e1-7.

12. Neuenhahn M, Albrecht J, Odendahl M, Schlott F, Dossinger G, Schiemann $\mathrm{M}$, et al. Transfer of minimally manipulated CMV-specific T cells from stem 
cell or third-party donors to treat CMV infection after Allo-HSCT. Leukemia. 2017;31(10):2161-71.

13. Full F, Lehner M, Thonn V, Goetz G, Scholz B, Kaufmann KB, et al. T cells engineered with a cytomegalovirus-specific chimeric immunoreceptor. J Virol. 2010;84(8):4083-8.

14. Rossig C, Bollard CM, Nuchtern JG, Rooney CM, Brenner MK. Epstein-Barr virusspecific human T lymphocytes expressing antitumor chimeric T-cell receptors: potential for improved immunotherapy. Blood. 2002;99(6):2009-16.

15. Roddie C, Peggs KS. Immunotherapy for transplantation-associated viral infections. J Clin Invest. 2017;127(7):2513-22.

16. Barrett AJ, Prockop S, Bollard CM. Virus-specific T cells: broadening applicability. Biol Blood Marrow Transplant. 2018;24(1):13-8.

17. Baugh KA, Tzannou I, Leen AM. Infusion of cytotoxic T lymphocytes for the treatment of viral infections in hematopoetic stem cell transplant patients. Curr Opin Infect Dis. 2018;31(4):292-300.

18. Kolb HJ, Mittermuller J, Clemm C, Holler E, Ledderose G, Brehm G, et al. Donor leukocyte transfusions for treatment of recurrent chronic myelogenous leukemia in marrow transplant patients. Blood. 1990;76(12):2462-5.

19. Papadopoulos EB, Ladanyi M, Emanuel D, Mackinnon S, Boulad F, Carabasi $\mathrm{MH}$, et al. Infusions of donor leukocytes to treat Epstein-Barr virus-associated lymphoproliferative disorders after allogeneic bone marrow transplantation. N Engl J Med. 1994;330(17):1185-91.

20. Leen AM, Tripic T, Rooney CM. Challenges of T cell therapies for virusassociated diseases after hematopoietic stem cell transplantation. Expert Opin Biol Ther. 2010;10(3):337-51.

21. Riddell SR, Greenberg PD. The use of anti-CD3 and anti-CD28 monoclonal antibodies to clone and expand human antigen-specific T cells. J Immunol Methods. 1990:128(2):189-201.

22. Riddell SR, Watanabe KS, Goodrich JM, Li CR, Agha ME, Greenberg PD. Restoration of viral immunity in immunodeficient humans by the adoptive transfer of T cell clones. Science. 1992;257(5067):238-41.

23. Einsele H, Roosnek E, Rufer N, Sinzger C, Riegler S, Loffler J, et al. Infusion of cytomegalovirus (CMV)-specific T cells for the treatment of CMV infection not responding to antiviral chemotherapy. Blood. 2002;99(11):3916-22.

24. Peggs K, Verfuerth S, Mackinnon S. Induction of cytomegalovirus (CMV)specific T-cell responses using dendritic cells pulsed with CMV antigen: a novel culture system free of live CMV virions. Blood. 2001;97(4):994-1000.

25. Rooney CM, Smith CA, Ng CY, Loftin S, Li C, Krance RA, et al. Use of genemodified virus-specific T lymphocytes to control Epstein-Barr-virus-related lymphoproliferation. Lancet. 1995;345(8941):9-13.

26. Rooney CM, Smith CA, Ng CY, Loftin SK, Sixbey JW, Gan Y, et al. Infusion of cytotoxic T cells for the prevention and treatment of Epstein-Barr virus-induced lymphoma in allogeneic transplant recipients. Blood. 1998;92(5):1549-55.

27. Tan R, Xu X, Ogg GS, Hansasuta P, Dong T, Rostron T, et al. Rapid death of adoptively transferred $T$ cells in acquired immunodeficiency syndrome. Blood. 1999:93(5):1506-10.

28. Feuchtinger T, Opherk K, Bethge WA, Topp MS, Schuster FR, Weissinger EM, et al. Adoptive transfer of pp65-specific T cells for the treatment of chemorefractory cytomegalovirus disease or reactivation after haploidentical and matched unrelated stem cell transplantation. Blood. 2010;116(20):4360-7.

29. Icheva V, Kayser S, Wolff D, Tuve S, Kyzirakos C, Bethge W, et al. Adoptive transfer of Epstein-Barr virus (EBV) nuclear antigen 1-specific T cells as treatment for EBV reactivation and lymphoproliferative disorders after allogeneic stem-cell transplantation. J Clin Oncol. 2012;31(1):39-48.

30. Feucht J, Opherk K, Lang P, Kayser S, Hartl L, Bethge W, et al. Adoptive T-cell therapy with hexon-specific THELPER-1 cells as a treatment for refractory adenovirus infection after HSCT. Blood. 2015;125(12):1986-94.

31. Khanna N, Stuehler C, Conrad B, Lurati S, Krappmann S, Einsele H, et al. Generation of a multipathogen-specific T-cell product for adoptive immunotherapy based on activation-dependent expression of CD154 Blood. 2011;118(4):1121-31.

32. Altman JD, Moss PA, Goulder PJ, Barouch DH, McHeyzer-Williams MG, Bell II, et al. Phenotypic analysis of antigen-specific T lymphocytes. Science. 1996;274(5284):94-6.

33. Gutgemann I, Fahrer AM, Altman JD, Davis MM, Chien YH. Induction of rapid T cell activation and tolerance by systemic presentation of an orally administered antigen. Immunity. 1998;8(6):667-73.

34. Keenan RD, Ainsworth J, Khan N, Bruton R, Cobbold M, Assenmacher M, et al. Purification of cytomegalovirus-specific CD8 T cells from peripheral blood using HLA-peptide tetramers. Br J Haematol. 2001;115(2):428-34.
35. Knabel M, Franz TJ, Schiemann M, Wulf A, Villmow B, Schmidt B, et al. Reversible MHC multimer staining for functional isolation of T-cell populations and effective adoptive transfer. Nat Med. 2002;8(6):631-7.

36. Manz R, Assenmacher M, Pfluger E, Miltenyi S, Radbruch A. Analysis and sorting of live cells according to secreted molecules, relocated to a cellsurface affinity matrix. Proc Natl Acad Sci U S A. 1995;92(6):1921-5.

37. Brosterhus H, Brings S, Leyendeckers H, Manz RA, Miltenyi S, Radbruch A, et al. Enrichment and detection of live antigen-specific CD4(+) and CD8(+) T cells based on cytokine secretion. Eur J Immunol. 1999;29(12):4053-9.

38. Wolfl M, Kuball J, Ho WY, Nguyen H, Manley TJ, Bleakley M, et al. Activationinduced expression of $\mathrm{CD} 137$ permits detection, isolation, and expansion of the full repertoire of CD8+ T cells responding to antigen without requiring knowledge of epitope specificities. Blood. 2007;110(1):201-10.

39. Frentsch M, Arbach O, Kirchhoff D, Moewes B, Worm M, Rothe M, et al. Direct access to CD4+ $T$ cells specific for defined antigens according to CD154 expression. Nat Med. 2005;11(10):1118-24.

40. Leen AM, Myers GD, Sili U, Huls MH, Weiss H, Leung KS, et al. Monoculturederived T lymphocytes specific for multiple viruses expand and produce clinically relevant effects in immunocompromised individuals. Nat Med. 2006;12(10):1160-6.

41. Fujita Y, Leen AM, Sun J, Nakazawa Y, Yvon E, Heslop HE, et al. Exploiting cytokine secretion to rapidly produce multivirus-specific T cells for adoptive immunotherapy. J Immunother. 2008;31(7):665-74.

42. Gerdemann U, Vera JF, Rooney CM, Leen AM. Generation of multivirusspecific T cells to prevent/treat viral infections after allogeneic hematopoietic stem cell transplant. J Vis Exp. 2011;(51).

43. Kallay K, Kassa C, Reti M, Karaszi E, Sinko J, Goda V, et al. Early experience with CliniMACS prodigy CCS (IFN-gamma) system in selection of virusspecific $T$ cells from third-party donors for pediatric patients with severe viral infections after hematopoietic stem cell transplantation. J Immunother. 2018;41(3):158-63.

44. Zandvliet ML, van Liempt E, Jedema I, Kruithof S, Kester MG, Guchelaar HJ, et al. Simultaneous isolation of CD8(+) and CD4(+) T cells specific for multiple viruses for broad antiviral immune reconstitution after allogeneic stem cell transplantation. J Immunother. 2011;34(3):307-19.

45. Walter EA, Greenberg PD, Gilbert MJ, Finch RJ, Watanabe KS, Thomas ED, et al. Reconstitution of cellular immunity against cytomegalovirus in recipients of allogeneic bone marrow by transfer of T-cell clones from the donor. $\mathrm{N}$ Engl J Med. 1995;333(16):1038-44.

46. Peggs KS, Verfuerth S, Pizzey A, Khan N, Guiver M, Moss PA, et al. Adoptive cellular therapy for early cytomegalovirus infection after allogeneic stem-cell transplantation with virus-specific T-cell lines. Lancet. 2003;362(9393):1375-7.

47. Cobbold M, Khan N, Pourgheysari B, Tauro S, McDonald D, Osman H, et al. Adoptive transfer of cytomegalovirus-specific CTL to stem cell transplant patients after selection by HLA-peptide tetramers. J Exp Med. 2005;202(3):379-86.

48. Schmitt A, Tonn T, Busch DH, Grigoleit GU, Einsele H, Odendahl M, et al. Adoptive transfer and selective reconstitution of streptamer-selected cytomegalovirus-specific CD8+ T cells leads to virus clearance in patients after allogeneic peripheral blood stem cell transplantation. Transfusion. 2011;51(3):591-9.

49. Heslop HE, Slobod KS, Pule MA, Hale GA, Rousseau A, Smith CA, et al. Longterm outcome of EBV-specific T-cell infusions to prevent or treat EBV-related lymphoproliferative disease in transplant recipients. Blood. 2010;115(5):925-35.

50. Haque T, Wilkie GM, Taylor C, Amlot PL, Murad P, lley A, et al. Treatment of Epstein-Barr-virus-positive post-transplantation lymphoproliferative disease with partly HLA-matched allogeneic cytotoxic T cells. Lancet. 2002; 360(9331):436-42

51. Haque $T$, Wilkie $G M$, Jones $M M$, Higgins $C D$, Urquhart $G$, Wingate $P$, et al. Allogeneic cytotoxic T-cell therapy for EBV-positive posttransplantation lymphoproliferative disease: results of a phase 2 multicenter clinical trial. Blood. 2007;110(4):1123-31.

52. Feuchtinger T, Matthes-Martin S, Richard C, Lion T, Fuhrer M, Hamprecht $K$, et al. Safe adoptive transfer of virus-specific T-cell immunity for the treatment of systemic adenovirus infection after allogeneic stem cell transplantation. Br J Haematol. 2006;134(1):64-76.

53. Geyeregger R, Freimuller C, Stemberger J, Artwohl M, Witt V, Lion T, et al. First-in-man clinical results with good manufacturing practice (GMP)compliant polypeptide-expanded adenovirus-specific T cells after haploidentical hematopoietic stem cell transplantation. J Immunother. 2014; 37(4):245-9. 
54. Leen AM, Christin A, Myers GD, Liu H, Cruz CR, Hanley PJ, et al. Cytotoxic T lymphocyte therapy with donor $\mathrm{T}$ cells prevents and treats adenovirus and Epstein-Barr virus infections after haploidentical and matched unrelated stem cell transplantation. Blood. 2009:114(19):4283-92.

55. Withers B, Blyth E, Clancy LE, Yong A, Fraser C, Burgess J, et al. Long-term control of recurrent or refractory viral infections after allogeneic HSCT with third-party virus-specific T cells. Blood Adv. 2017; (24):2193-205.

56. Perruccio K, Tosti A, Burchielli E, Topini F, Ruggeri L, Carotti A, et al. Transferring functional immune responses to pathogens after haploidentical hematopoietic transplantation. Blood. 2005;106(13):4397-406.

57. Meij P, Jedema I, Zandvliet ML, van der Heiden PL, van de Meent M, van Egmond $\mathrm{HM}$, et al. Effective treatment of refractory CMV reactivation after allogeneic stem cell transplantation with in vitro-generated CMV pp65specific CD8+ T-cell lines. J Immunother. 2012;35(8):621-8.

58. Pei XY, Zhao XY, Chang YJ, Liu J, Xu LP, Wang Y, et al. Cytomegalovirusspecific T-cell transfer for refractory cytomegalovirus infection after Haploidentical stem cell transplantation: the quantitative and qualitative immune recovery for cytomegalovirus. J Infect Dis. 2017;216(8):945-56.

59. Withers B, Clancy L, Burgess J, Simms R, Brown R, Micklethwaite K, et al. Establishment and operation of a third-party virus-specific T cell Bank within an allogeneic stem cell transplant program. Biol Blood Marrow Transplant. 2018:24(12):2433-42

60. Uhlin M, Gertow J, Uzunel M, Okas M, Berglund S, Watz E, et al. Rapid salvage treatment with virus-specific T cells for therapy-resistant disease. Clin Infect Dis. 2012;55(8):1064-73.

61. Blyth E, Clancy L, Simms R, Ma CK, Burgess J, Deo S, et al. Donor-derived CMV-specific T cells reduce the requirement for CMV-directed pharmacotherapy after allogeneic stem cell transplantation. Blood. 2013; 121(18):3745-58

62. Peggs KS, Thomson K, Samuel E, Dyer G, Armoogum J, Chakraverty R, et al. Directly selected cytomegalovirus-reactive donor T cells confer rapid and safe systemic reconstitution of virus-specific immunity following stem cell transplantation. Clin Infect Dis. 2011;52(1):49-57.

63. Doubrovina E, Oflaz-Sozmen B, Prockop SE, Kernan NA, Abramson S, TeruyaFeldstein J, et al. Adoptive immunotherapy with unselected or EBV-specific $T$ cells for biopsy-proven EBV+ lymphomas after allogeneic hematopoietic cell transplantation. Blood. 2012:119(11):2644-56.

64. Gallot G, Vollant S, Saiagh S, Clemenceau B, Vivien R, Cerato E, et al. T-cell therapy using a bank of EBV-specific cytotoxic T cells: lessons from a phase I/I feasibility and safety study. J Immunother. 2014;37(3):170-9.

65. Uhlin M, Okas M, Gertow J, Uzunel M, Brismar TB, Mattsson J. A novel haploidentical adoptive CTL therapy as a treatment for EBV-associated lymphoma after stem cell transplantation. Cancer Immunol Immunother. 2010;59(3):473-7.

66. Moosmann A, Bigalke I, Tischer J, Schirrmann L, Kasten J, Tippmer S, et al. Effective and long-term control of EBV PTLD after transfer of peptideselected T cells. Blood. 2010;115(14):2960-70.

67. Qasim W, Gilmour K, Zhan H, Derniame S, McNicol AM, Ip W, et al. Interferon-gamma capture T cell therapy for persistent Adenoviraemia following allogeneic haematopoietic stem cell transplantation. $\mathrm{Br} J$ Haematol. 2013;161(3):449-52.

68. Gerdemann U, Katari UL, Papadopoulou A, Keirnan JM, Craddock JA, Liu H, et al. Safety and clinical efficacy of rapidly-generated trivirus-directed T cells as treatment for adenovirus, EBV, and CMV infections after allogeneic hematopoietic stem cell transplant. Mol Ther. 2013;21(11):2113-21.

\section{Ready to submit your research? Choose BMC and benefit from:}

- fast, convenient online submission

- thorough peer review by experienced researchers in your field

- rapid publication on acceptance

- support for research data, including large and complex data types

- gold Open Access which fosters wider collaboration and increased citations

- maximum visibility for your research: over $100 \mathrm{M}$ website views per year

At $\mathrm{BMC}$, research is always in progress.

Learn more biomedcentral.com/submissions 